\title{
Structural, histochemical and photosynthetic profiles of galls induced by Eugeniamyia dispar (Diptera: Cecidomyiidae) on the leaves of Eugenia uniflora (Myrtaceae)
}

\author{
Uiara Costa Rezende ${ }^{1}$, Ana Silvia Franco Pinheiro Moreira ${ }^{2}$, Vinícius Coelho Kuster ${ }^{1}$ \\ $\&$ Denis Coelho de Oliveira ${ }^{{ }^{*}}$ \\ 1. Laboratório de Anatomia Desenvolvimento Vegetal e Interações, Universidade Federal de Uberlândia, Av. Pará 1720, CEP \\ 38400-902, Campus Umuarama, Minas Gerais, Brasil; uiara.ucr@gmail.com, viniciusck_bio@hotmail.com, \\ denisoliveira@ufu.br \\ 2. Laboratório de Fisiologia Vegetal, Universidade Federal de Uberlândia, Av. Pará 1720, CEP 38400-902, Campus Umuarama, \\ Minas Gerais, Brasil; anasilvia@inbio.ufu.br \\ * Correspondence
}

Received 03-VII-2018. C Corrected 26-VII-2018. $\quad$ Accepted 28-VIII-2018.

\begin{abstract}
Gall-inducing insects manipulate the structural, histochemical and physiological profiles of host-plant tissues to develop galls. We evaluated galls induced by Eugeniamyia dispar on the leaves of Eugenia uniflora in an attempt to answer the following questions: (i) How does this gall-inducing insect change the structural and histochemical profiles of the host-plant organ? (ii) Despite structural changes, can gall tissues maintain photosynthetic activity? Starch, proteins, reducing sugars and reactive oxygen species were detected mainly in the nutritive tissue surrounding the larval chamber. Despite structural changes, the galls induced by E. dispar on E. uniflora retain chlorophyllous tissue, although its amount and photosynthetic activity are less than that of non-galled leaves. This reduced photosynthetic activity, in association with the presence of large intercellular spaces, could improve gas diffusion and, consequently, avoid hypoxia and hypercarbia in gall tissue.
\end{abstract}

Key words: Chlorophyll $a$ fluorescence; photosynthetic pigments; protein storage; reactive oxygen species; tissue gradients.

Costa Rezende, U., Pinheiro Moreira, A. S. F., Coelho Kuster, V. \& Coelho de Oliveira, D. (2018). Structural, histochemical and photosynthetic profiles of galls induced by Eugeniamyia dispar (Diptera: Cecidomyiidae) on the leaves of Eugenia uniflora (Myrtaceae). Revista de Biología Tropical, 66(4), 1469-1480.

Galls are neoformed plant organs (Shorthouse, Wool, \& Raman, 2005) developed from host-plant tissues as a result of cell multiplication and re-differentiation (sensu Lev-Yadun, 2003) after induction by gall-inducing organisms (Raman, Cruz, Muniappan, \& Reddy, 2007; Oliveira et al., 2016). These neoformed plant organs possesses cells with new fates and rapid cell cycles (Carneiro \& Isaias, 2015), which can provide nutrition and protection against environment stressors and natural enemies for the gall-inducing organism (Price, Fernandes, \& Warring, 1987; Stone \& Schönrogge, 2003; Formiga, Gonçalves, Soares, \& Isaias, 2009; Formiga, Soares, \& Isaias, 2011). Insects generally induce well-defined galls, which are considered the most specialized because they encompass a great diversity of morphotypes (Roskam, 1992; Raman, Schaefer, \& Withers, 2005; Isaias, Carneiro, Oliveira, \& Santos, 2013). In the Neotropics, galls are induced mostly by species of the family 
Cecidomyiidae (Gagné, 1994; Fernandes \& Santos, 2014). The species Eugeniamyia dispar Maia, Mendonça, \& Romanowski 1996 (Diptera: Cecidomyiidae), for example, induces pale green galls on the adaxial surface of young leaves of Eugenia uniflora L. (Myrtaceae). In this system new galls are being induced, developing and going through senescence throughout the year (Mendonça \& Romanowski, 2002).

The feeding of gall-inducing insects induces stress in host-plant cells, which can be detected by the presence of hydrogen peroxide, a reactive oxygen species (ROS) (Isaias, Coelho, \& Carneiro, 2011; Oliveira, Isaias, Moreira, Magalhães, \& Lemos-Filho, 2011b; Isaias, Oliveira, Moreira, Soares, \& Carneiro, 2015; Oliveira et al., 2016). These molecules were initially recognized as unhealthy for plant cells since they are able to cause damage to a variety of cellular structures (Petrov \& Van Breusegem, 2012). However, they can also play an important role in molecular signaling during plant organ development (Del Río \& Puppo, 2009), and consequently in gall morphogenesis and physiology (Isaias et al., 2015; Oliveira et al., 2016). Among the changes caused by the feeding activity of gall-inducing insects is the accumulation of primary metabolites (Bronner, 1992). Cecidomyiid galls, for example, possess a histochemical gradient associated with a large accumulation of certain primary metabolites near the larval chamber, thereby forming nutritive tissue, while others (such as starch) accumulate more distant from the larval chamber and are known as reserve tissues (Bronner, 1992; Ferreira, Álvarez, Avritzer, \& Isaias, 2017). In addition to nutritive tissue formation, structural and physiological alterations, such as decreases in the amount of chlorophyllous tissues, pigment content, gas exchange, and photosynthetic rates, have been detected in gall tissues (Florentine, Raman, \& Dhileepan, 2005; Oliveira et al., 2011b; Oliveira, Moreira, Isaias, Martini, \& Rezende, 2017). Nonetheless, green galls should maintain their photosynthetic activity in spite of the oxidative stress and structural changes caused by the gall-inducing organism. This maintenance of photosynthetic activity would have interesting implications for the oxygen and carbon dioxide cycle of galls by reducing hypoxia and hypercarbia (Castro, Oliveira, Moreira, Lemos-Filho, \& Isaias, 2012; Haiden, Hoffmann, \& Cramer, 2012; Oliveira et al., 2017).

Herein, we assess the structural, histochemical and physiological profiles of galls induced by E. dispar (Diptera: Cecidomyiidae) on leaves of E. uniflora (Myrtaceae). We address the following questions: (i) How does this gall-inducing insect changes the structural and histochemical profiles of the host-plant organ? (ii) Despite structural changes, can gall tissues maintain photosynthetic activity?

\section{MATERIALS AND METHODS}

Study area and plant material: Nongalled leaves and galls of E. dispar - E. uniflora were sampled from vegetation on the campus of the Universidade Federal de Uberlândia (1853"7.8' S - 48 $15^{\circ}$ "36' W, Uberlândia), Minas Gerais, Brazil. The sampled plants $(n=5)$ were pruned to provoke periodical new leaf flushes, and thus maintain gall populations throughout the year. The samples were collected between January and April 2015.

Anatomical and histochemical analyses: Anatomical and histochemical analyses were performed with non-galled leaves $(\mathrm{n}=10)$ and mature galls $(n=10)$, both from the third node. Galls were considered as mature from the formation of a distinguishable larval chamber until the exit of the insect. For structural analysis, samples were fixed in FAA (formalin, acetic acid, $50 \%$ ethanol, 1:1:18 v/v/v) for 48 hours (Johansen, 1940), dehydrated in an ethanol series, embedded in 2-hydroxyethyl methacrylate (Historesin, Leica ${ }^{\circledR}$ Instruments, Germany), and sectioned using a rotary microtome (YD-315 model, China) at a thickness of 4-5 $\mu \mathrm{m}$. The sections were stained with $1 \%$ toluidine blue at $\mathrm{pH} 4.0$ (O'Brien, Feder, \& McCully, 1964) and mounted with Entellan ${ }^{\circledR}$.

Histochemical analyses were performed on samples embedded in polyethylenoglycol 
(PEG 6000) (Ferreira, Teixeira, \& Isaias, 2014) and sectioned in a rotary microtome at a thickness of $25 \mu \mathrm{m}$, or on free-hand sections (using razor blades) obtained from recently collected non-galled and galled samples. Lugol's test was used for detection of starch (Johansen, 1940); bromophenol blue for total protein (Baker, 1958); Sudan Red B for total lipids (Brundett, Kendrick, \& Peterson, 1991); Fehling's reagent for reducing sugars (Sass, 1951); and the DAB test " $0.5 \% 3,3$ 'diaminobenzidine" (DAB Sigma ${ }^{\circledR}$ ) for hydrogen peroxide (Rossetti \& Bonnatti, 2001). Control tests were conducted as recommended for each of the histochemical tests, while comparisons were also made using non-stained sections.

All samples were analyzed and photographed with a Leica ${ }^{\circledR}$ DM500 photomicroscope coupled to a Leica ${ }^{\circledR}$ ICC50HD camera. The area occupied by the chlorophyllous tissues was measured using the software Image Pro-Plus (version 4.1 for Windows ${ }^{\circledR}$, Media Cybernetics).

Photosynthetic performance and content of photosynthetic pigments: Photosynthetic performance of non-galled leaves ( $\mathrm{n}$ $=6$ ) and mature galls $(\mathrm{n}=6)$, both from the third node, was evaluated by chlorophyll $a$ fluorescence using a Handy FluorCam-PSI (Photon Systems Instruments). The samples were covered for 30 minutes (dark adaptation) prior to evaluation in the laboratory, and the photosynthetic parameters reported according Genty, Briantais and Baker (1989) and Oxborough (2004). The following photosynthetic parameters were evaluated using Fluorcam7 software (protocol Quenching): $\mathrm{F}_{0}$ $=$ minimal fluorescence in dark-adapted state; $\mathrm{F}_{\mathrm{m}}=$ maximum fluorescence in dark-adapted state; $\mathrm{F}_{\mathrm{v}} / \mathrm{F}_{\mathrm{m}}=$ maximum quantum yield; NPQ $=$ non-photochemical quenching during light adaptation; $\mathrm{R}_{\mathrm{fd}}=$ fluorescence decline ratio in steady-state (an empirical parameter used to assess plant vitality); and (F'm-F')/F'm = PSII operating efficiency (where F'm is the fluorescence signal when all PSII centers are closed in the light-adapted state, and F' is the measurement of the light-adapted fluorescence signal).

Photosynthetic pigment content was determined for $0.8-\mathrm{cm}^{2}$ disks taken from non-galled leaves ( $n=30$, six leaves per plant, five plants) and mature galls $(n=30)$. The samples were weighed and immersed in $5 \mathrm{ml}$ of $80 \%$ acetone for 48 hours, macerated and centrifuged at 3 $000 \mathrm{rpm}[\mathrm{G}]$ for three minutes. The extracts were analyzed in a UV- VIS spectrophotometer (SP-220 model, Biospectro, Brazil) at wavelengths of 470, 646 and $663 \mathrm{~nm}$. Chlorophyll $a$, $b$, and carotenoid levels were measured following Lichtenthaler and Wellburn (1983).

Statistical analyses: Physiological analyses of galls and non-galled leaves were compared using means and standard deviations calculated using $\mathrm{JMP}^{\circledR} 4$ software (SAS Institute).

\section{RESULTS}

Morphological and anatomical features: The leaves of E. uniflora are simple, glabrous, oblong-lanceolate with entire margins and opposite phyllotaxy (Fig. 1a). In cross section, they are hypostomatic, with a uniseriate epidermis and mesophyll comprising two layers of palisade parenchyma and about nine layers of spongy parenchyma. Secretory canals occur in the mesophyll (Fig. 1b).

The E. dispar - E. uniflora galls possess a globular shape and occur singly or in clusters (Fig. 1a, Fig. 1b and Fig. 1c). They are intralaminar, projecting on both leaf surfaces, and contain a single larval chamber occupied by one gall-inducing insect larva when the gall occurs singly (Fig. 1d). The galls possess chlorophyllous tissue particularly in the adaxial surface (Fig. 1d). Structural analysis of the galls revealed an uniseriate epidermis (Fig. 2a, Fig. 2b y Fig. 2c) with secretory canals below (Fig. 2c). The cells of the cortex are anticlinally elongated (Fig. 2d, Fig. 2e), with large intercellular spaces mainly among the outer layers (Fig. 2d). Around the larval chamber the tissue is compact and without any intercellular spaces 


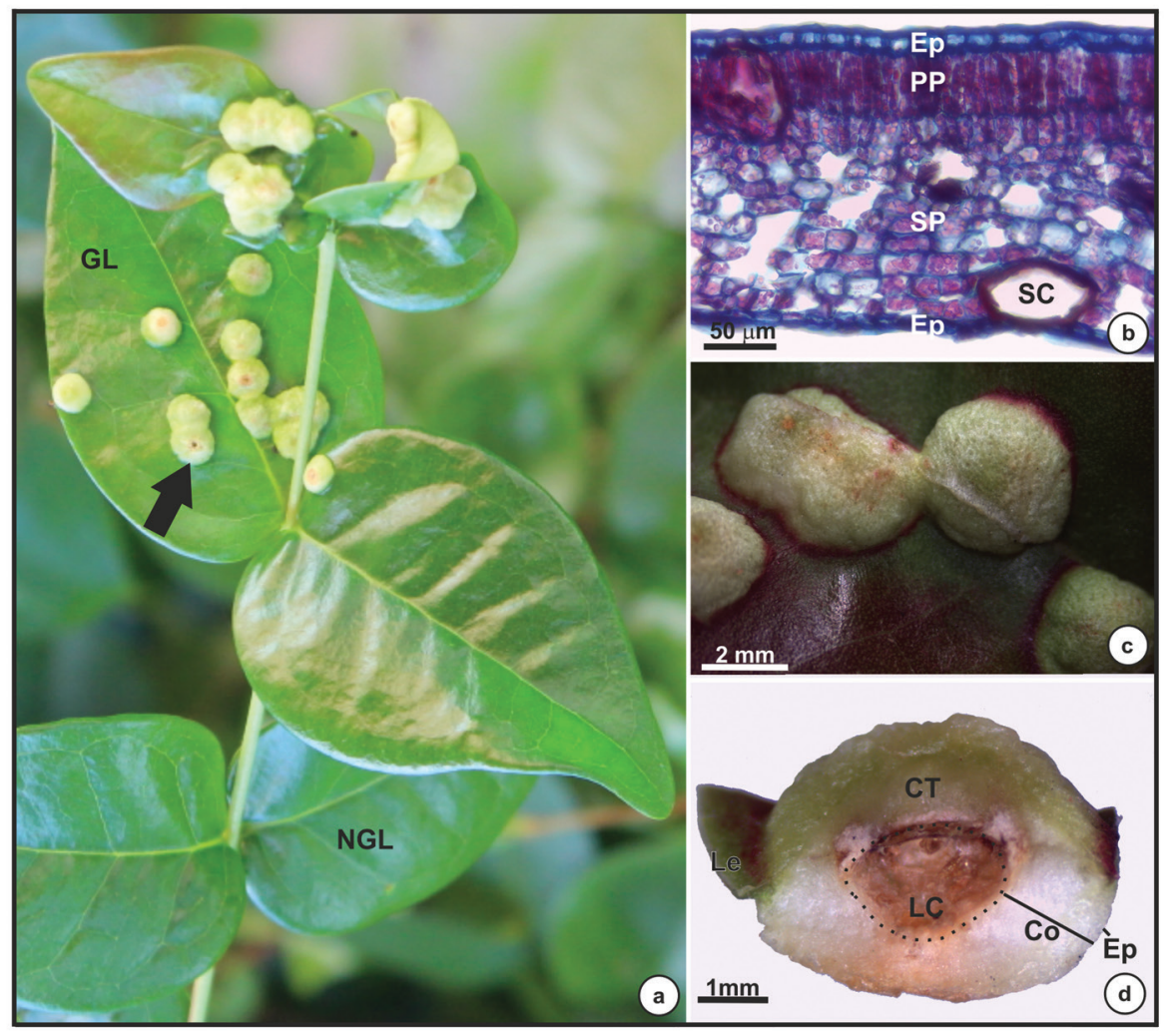

Fig. 1. Morphological and anatomical characteristics of non-galled leaves and galls induced by Eugeniamyia dispar on Eugenia uniflora leaves. a- Branch with non-galled leaves and galls. Arrow indicates a gall; b- anatomical detail of nongalled leaf in cross section; c- macroscopic view of galls; d- cross section of gall. Abbreviation: GL- galled leaf; NGL- nongalled leaf; Ep- epidermis; PP- palisade parenchyma; SP- spongy parenchyma; SC- secretory cavity; CT- chlorophyllous tissue; LC- larval chamber; Co- cortex; Le- leaf.

(Fig. 2e). Vascular bundles are distributed around the larval chamber and ramify laterally (Fig. 2a, Fig. 2e, Fig. 2f). At maturity, most of the nutritive tissue of the galls is partially or totally absent.

Histochemical profile: Starch grains (Fig. 3a), proteins (Fig. 3b) and reducing sugars (Fig. $3 c$ ) were detected in the galls but only around the larval chamber, while lipid substances were detected in the secretory canals (Fig. 3d). The DAB test for oxidative stress revealed the presence of hydrogen peroxide (a ROS molecule) especially in the epidermis (Fig. 3e), secretory canals (Fig. 3f) and vascular bundles around the larval chamber (Fig. 3g).
Pigment content and chlorophyll $a$ fluorescence: Total chlorophyll and carotenoids were higher in non-galled leaves (Average AV $=2.7 \pm$ Standard Error $\mathrm{SE}=0.2$ and $\mathrm{AV}=0.3$ $\pm \mathrm{SE}=0.02 \mathrm{mg} \mathrm{g}^{-2}$ of fresh mass, respectively) than in galls $(\mathrm{AV}=1.3 \pm \mathrm{SE}=0.1$ and $\mathrm{AV}=0.2$ $\pm \mathrm{SE}=0.03 \mathrm{mg} \mathrm{g}^{-2}$ of fresh mass, respectively); however, the ratio of chlorophyll $a / b$ was simi$\operatorname{lar}(\mathrm{AV}=1.7 \pm \mathrm{SE}=0.2$ and $\mathrm{AV}=2.1 \pm \mathrm{SE}$ $=0.1$ for non-galled leaves and galls, respectively). The chlorophyll/carotenoids ratio was higher in non-galled than galled tissues $(\mathrm{AV}=$ $9.6 \pm \mathrm{SE}=1.2$ and $\mathrm{AV}=6.3 \pm \mathrm{SE}=0.4$, respectively) (Table 1).

Galls exhibited different values for the chlorophyll fluorescence parameters when 
TABLE 1

Means and standard errors of photosynthetic pigments ( $\mathrm{mg} \mathrm{g}^{-2}$ of fresh mass) in non-galled leaves and galls induced by Eugeniamyia dispar on Eugenia uniflora leaves

\begin{tabular}{lcccc}
\multicolumn{1}{c}{ Samples } & \multicolumn{3}{c}{ Parameters } \\
& Total chlorophyll & Carotenoids & Chlorophyll a/b & Chlorophyll/carotenoids \\
Non-galled leaves & $2.72 \pm 0.19 a$ & $0.31 \pm 0.024 a$ & $1.73 \pm 0.15 a$ & $9.55 \pm 1.16 a$ \\
Galls & $1.28 \pm 0.12 b$ & $0.22 \pm 0.029 b$ & $2.13 \pm 0.14 a$ & $6.27 \pm 0.38 b$ \\
\hline
\end{tabular}

*Means followed by different letters differ statistically within the same parameter $(\mathrm{P}<0.05)$.

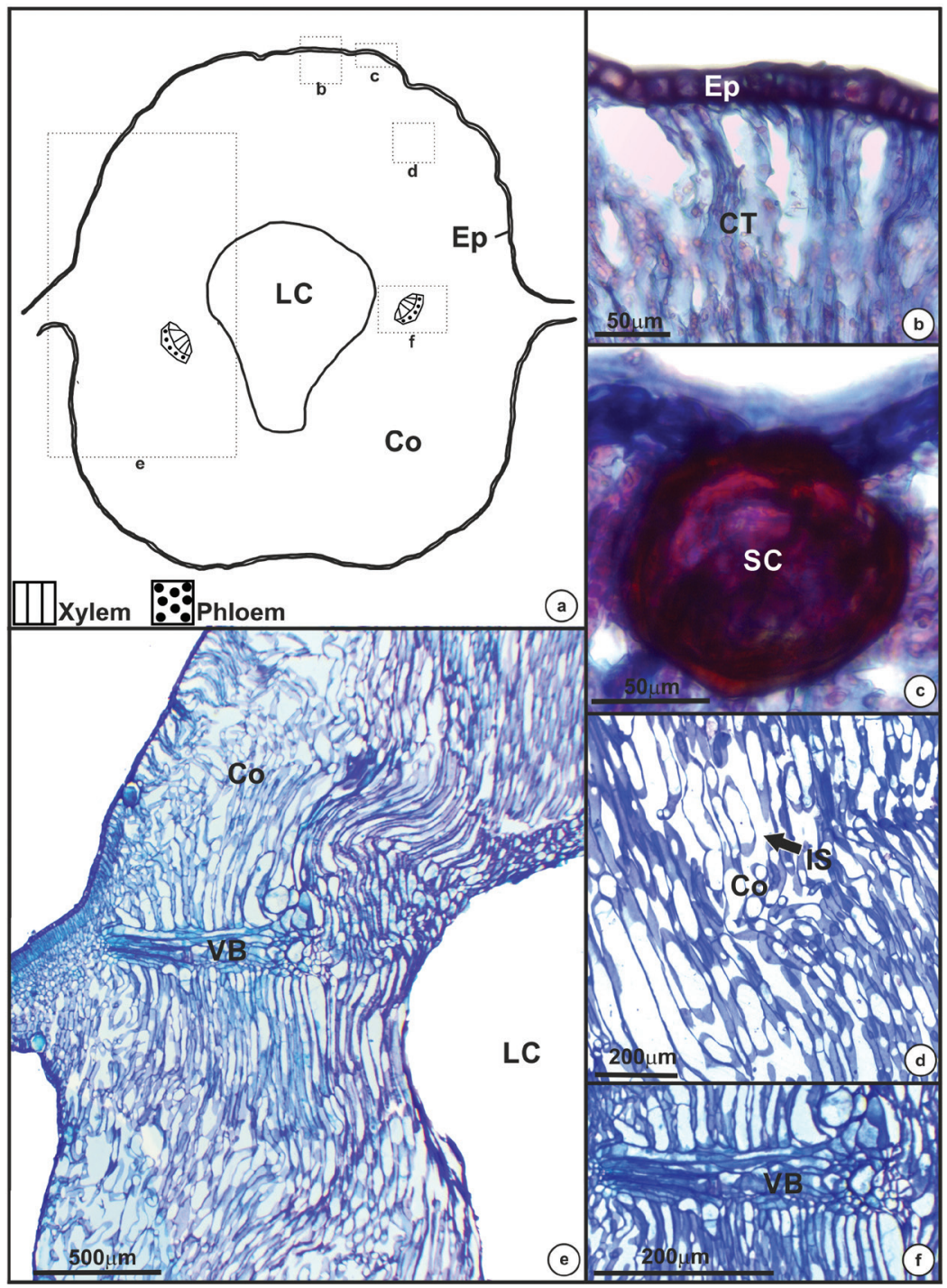

Fig. 2. Anatomic structure of mature galls of Eugenia uniflora induced by Eugeniamyia dispar. a- Schematic representing gall shape and regions where the anatomy is highlighted; b- uniseriate epidermis; c- secretory cavity; d- outer layers of the cortex; e- one side of the gall, from the epidermis to the larval chamber; $\mathbf{f}$ - vascular bundle. Abbreviation: Ep- epidermis; Co- cortex; LC- larval chamber; CT- chlorophyllous tissue; SC- secretory cavity; IS- intercellular space; VB- vascular bundle. 


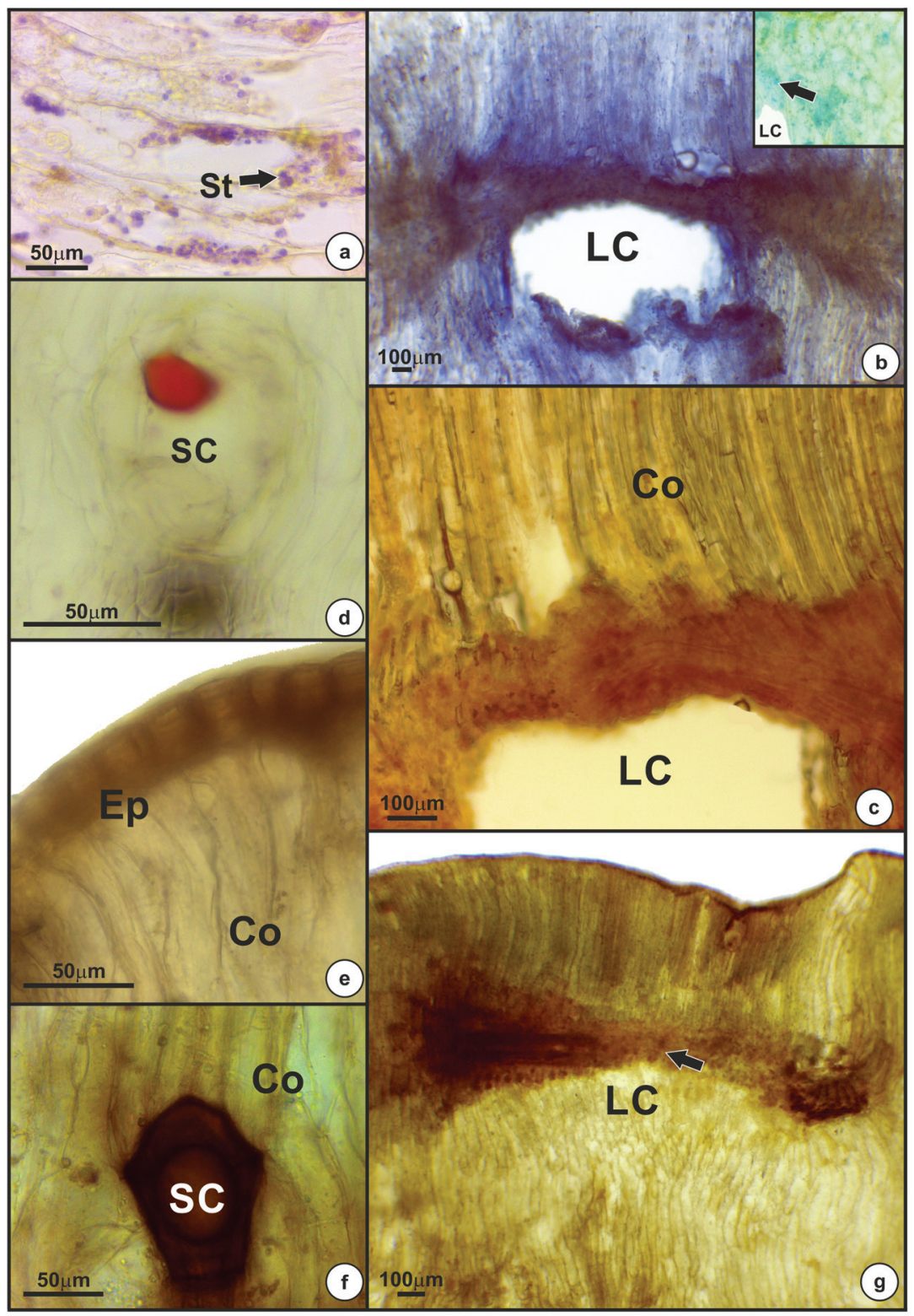

Fig. 3. Positive histochemical results for mature galls of Eugenia uniflora induced by Eugeniamyia dispar. a- Starch occurring near the larval chamber; b- proteins around the larval chamber; $\mathbf{c}$ - reducing sugar near the larval chamber; $\mathbf{d}$ - lipid compound detected in secretory cavity; $\mathbf{e}, \mathbf{f}$, g- oxidative stress occurs predominantly in the epidermis (e), secretory cavities (f) and in the vascular bundles near the larval chamber (g). Abbreviation: St- starch; LC- larval chamber; Co- cortex; SCsecretory cavity; Ep- epidermis.

compared with non-galled leaves (Table 2). The galled tissues had a higher minimal fluorescence of PSII in the dark-adapted state $\left(\mathrm{F}_{0}\right)$ than the non-galled tissues $(\mathrm{AV}=389.5 \pm \mathrm{SE}=$ 20.9 and $\mathrm{AV}=313.9 \pm \mathrm{SE}=12.7$, respectively).
The maximum fluorescence of PSII in the dark-adapted state $\left(\mathrm{F}_{\mathrm{m}}\right)$, the PSII operating efficiency $\left[\left(\mathrm{F}_{\mathrm{m}}{ }_{\mathrm{m}}-\mathrm{F}^{\prime}\right) / \mathrm{F}\right.$ 'm $]$, the maximum quantum yield $\left(\mathrm{F}_{\mathrm{v}} / \mathrm{F}_{\mathrm{m}}\right)$, and the fluorescence decline ratio in steady-state $\left(\mathrm{R}_{\mathrm{fd}}\right)$ were all higher in 
TABLE 2

Means and standard errors of chlorophyll $a$ fluorescence performed on non-galled leaves and galls induced by Eugeniamyia dispar on Eugenia uniflora leaves

\begin{tabular}{lcccccc}
\multicolumn{1}{c}{ Samples } & \multicolumn{5}{c}{ Parameters } \\
& $\mathrm{F}_{0}$ & $\mathrm{~F}_{\mathrm{m}}$ & $\left(\mathrm{F}_{\mathrm{m}}^{\prime} \mathrm{F}^{\prime}\right) / \mathrm{F}_{\mathrm{m}}^{\prime}$ & $\mathrm{Fv} / \mathrm{Fm}$ & $\mathrm{R}_{\mathrm{fd}}$ & $\mathrm{NPQ}$ \\
Non-galled leaves & $313.9 \pm 12.7 b$ & $1480.84 \pm 55.1 a$ & $0.77 \pm 0.06 a$ & $0.79 \pm 0.14 a$ & $2.41 \pm 0.19 a$ & $1.98 \pm 0.21 a$ \\
Galls & $389.53 \pm 20.9 a$ & $1259.45 \pm 61.8 b$ & $0.60 \pm 0.08 b$ & $0.69 \pm 0.08 b$ & $1.55 \pm 0.05 b$ & $1.92 \pm 0.19 a$ \\
\hline
\end{tabular}

*Means followed by different letters differ statistically within the same parameter $(\mathrm{P}<0.05)$.

$\mathrm{F}_{0}$ : minimal fluorescence in dark-adapted state; Fm: maximum fluorescence in dark-adapted state; (F'm-F')/F'm: PSII operating efficiency; Fv/Fm: maximum quantum yield; $\mathrm{R}_{\mathrm{fd}}$ : fluorescence decline ratio in steady-state; NPQ: nonphotochemical quenching during light adaptation.

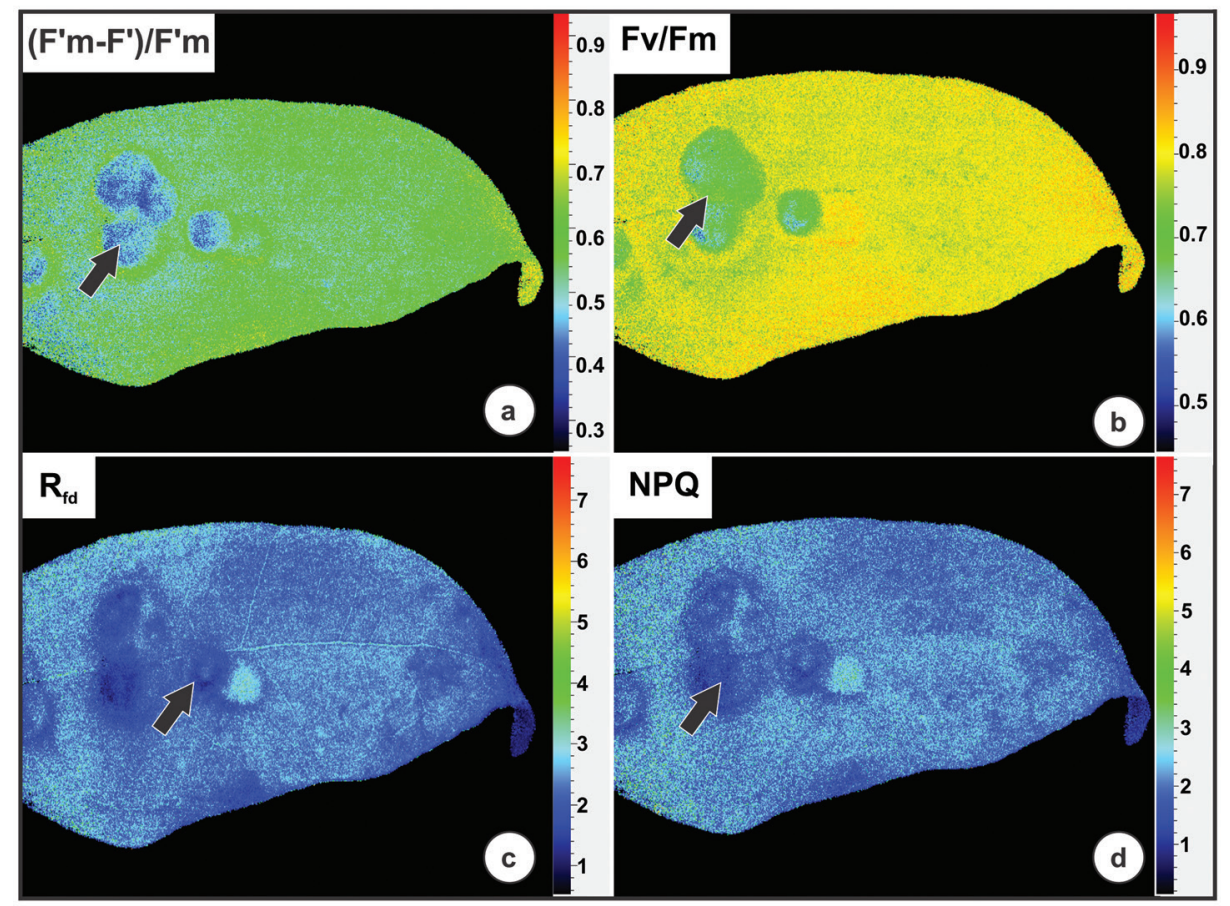

Fig. 4. Chlorophyll $a$ fluorescence performed on galls induced by Eugeniamyia dispar on Eugenia uniflora leaves. a- PSII operating efficiency $\left(\left(F^{\prime} m-F^{\prime}\right) / F^{\prime} m\right)$; b- the maximum quantum yield $(\mathrm{Fv} / \mathrm{Fm})$; c- fluorescence decline ratio in steady-state $\left(\mathrm{R}_{\mathrm{fd}}\right)$; d- energy dissipation through non-photochemical quenching (NPQ).

non-galled leaves than galled tissues (Fig. 4a, Fig 4b y Fig. 4c; Table 2). Energy dissipation through non-photochemical quenching (NPQ) did not differ between non-galled and galled tissues (Fig. 4d; Table 2).

\section{DISCUSSION}

Eugeniamyia dispar manipulates the tissues of E. uniflora to develop leaf galls.
Proteins and reducing sugars were detected mainly in the cells surrounding the larval chamber, which is a typical induced nutritional gradient for galls (Bronner, 1992). Although uncommon, starch was also detected in cells around the larval chamber. Reactive oxygen species (ROS) were detected around the larval chamber in association with primary metabolites, especially proteins, which is indicative of biotic stress (Schönrogge, Harper, \& 
Lichtenstein, 2000). Stress was also detected in gall tissues by chlorophyll $a$ fluorescence, which demonstrates that galls retain a low-level photosynthetic capacity, as observed in other Neotropical gall systems (Castro Oliveira, Moreira, Lemos-Filho, \& Isaias, 2012; Oliveira et al., 2017). Associated with low photosynthetic activity, many intercellular spaces may facilitate gas diffusion, as has been previously proposed for other gall systems (Pincebourde \& Casas, 2016).

Cell hypertrophy is the most important and convergent morphological feature induced by gall-inducing insects in their host-plants (Mani, 1964; Shorthouse \& Rohfritsch, 1992; Isaias, Oliveira, Carneiro, \& Kraus, 2014; Magalhães, Oliveira, Suzuki, \& Isaias, 2014; Oliveira et al., 2016; Carneiro, Isaias, Moreira, \& Oliveira, 2017). This process frequently leads to the formation of compact tissues, as observed in the horn-shaped galls and midrib galls induced by cecidomyiids on leaves of Copaifera langsdorffii Desf. (Fabaceae) (Oliveira \& Isaias, 2010a; Castro et al., 2012), in the intralaminar galls induced by sucking insects on Aspidosperma australe Müll.Arg (Apocynaceae) (Oliveira \& Isaias, 2010b), and in several other systems (Mani, 1964). The development of compact tissue is associated with a decrease of intercellular spaces and, consequently, a reduction of water loss (Heldt \& Piechulla, 2010; Castro et al., 2012) and a deceleration of gas diffusion in gall tissues (Pincebourde \& Casas, 2016). Despite the formation of compact tissues in different gall systems, the galls induced by E. dispar on leaves of E. uniflora have large intercellular spaces in the outer layers. These intercellular spaces may help to maintain gas diffusion and, consequently, avoid hypoxia and hypercarbia in gall tissues (Pincebourde \& Casas, 2016; Oliveira et al., 2017).

Galls induced by cecidomyiids commonly develop nutritive tissues around the larval chamber (Bronner, 1992; Ferreira et al., 2017). These nutritive tissues usually store proteins and reducing sugars that may be used as food by the gall-inducing insect larva (Bronner, 1992; Oliveira, Carneiro, Magalhaes, \&
Isaias, 2011a; Ferreira \& Isaias, 2013, 2014; Vecchi, Menezes, Oliveira, Ferreira, \& Isaias, 2013; Ferreira et al., 2017). In galls induced by species of Cecidomyiidae on leaves of Aspidosperma spruceanum Benth ex Müll. Arg. (Apocynaceae) and Piper arboreum Aubl. (Piperaceae), such proteins are associated with the high metabolism and oxidative stress caused by the gall-inducing insect (Schönrogge et al., 2000; Oliveira et al., 2011b; Bragança, Oliveira, \& Isaias, 2017), which also occurs with galls induced by $E$. dispar on E. uniflora. The starch and reducing sugars detected in the cells around the larval chamber of galls induced by $E$. dispar may function as energetic resources for both gall-inducing insect nutrition and maintenance of the cell machinery of the gall, as proposed for other systems (Oliveira et al., 2011a; Ferreira \& Isaias, 2013; Isaias et al., 2014; Oliveira et al., 2016; Bragança et al., 2017; Ferreira et al., 2017). Although uncommon in the nutritive tissue, starch grains have been detected in galls induced by cecidomyiids (Oliveira et al., 2011a). Lipids have been reported from galls produced by species of Cynipidae and Lepidoptera (Bronner, 1992; Vechi et al., 2013), and have also been detected in galls induced by species of Cecidomyiidae on A. spruceanum (Oliveira, Magalhães, Carneiro, Alvim, \& Isaias 2010), C. langsdorffii (Oliveira et al., 2011a), Marcetia taxifolia (A.St.-Hil.) DC. (Ferreira \& Isaias, 2014) and Lantana camara L. (Moura, Soares, \& Isaias, 2008). Although lipids are commonly produced by the intrinsic metabolism of leaves of E. uniflora (Victoria et al., 2012), these substances were not detected in the compact cortex of their galls and occur only in the secretory canals. These findings clearly indicate how insects can manipulate, and even block, some of the substances produced by the metabolism of the host-plant.

Even though the galls induced by E. dispar on leaves of E. uniflora retain chlorophyllous tissue in the outer layers of the gall cortex, the photosynthetic activity of this new organ is reduced. This reduction is likely due to an increase in oxidative stress induced by the 
gall-inducing insect, and a reduction in pigment content (Oliveira et al., 2011b; Isaias et al., 2015). The reduction in pigment content may be a consequence of cell hypertrophy and hyperplasia, which increases gall volume (Oliveira et al., 2017). The reduced area of chlorophyllous tissue in galls, compared to non-galled leaves, found in the present study may contribute to the decreased photosynthetic rate, as reported for other gall systems (Carneiro Castro, \& Isaias, 2014). A reduction in photosynthetic pigment content has also been reported for horn-shaped galls induced by species of Cecidomyiidae on leaflets of C. langsdorffii (Castro et al., 2012), and intralaminar galls on leaves of $A$. spruceanum (Oliveira et al., 2011b). This reduction also negatively affects the photosynthetic rates of the gall tissues. Carotenoids and NPQ are responsible for energy dissipation during the xanthophyll cycle and, consequently, prevent damage to the photosynthetic apparatus during stress (Demmig-Adams \& Adams, 1996). Contrary to expectations, there was a decrease in carotenoid content in gall tissues compared to non-galled leaves of E. uniflora, an indication that the gall tissue may invest in different mechanisms for stress dissipation and maintenance of tissue homeostasis (Isaias et al., 2015; Oliveira et al., 2017); we also detected a decrease of NPQ levels in galls induced by $E$. dispar on leaves of E. uniflora.

Studies of photosynthetic performance have shown that gall development may not alter photosynthetic rates in relation to nongalled organs (Fernandes et al., 2010; Oliveira et al., 2010, 2011b) or may even increase it (Bagatto, Paquette, \& Shorthouse, 1996). The maximum quantum efficiency of PSII $\left(\mathrm{F}_{\mathrm{v}} / \mathrm{F}_{\mathrm{m}}\right)$ and PSII operating efficiency $\left[\left(\mathrm{F}_{\mathrm{m}}{ }_{\mathrm{m}}-\mathrm{F}^{\prime}\right) / \mathrm{F}_{\mathrm{m}}{ }_{\mathrm{m}}\right]$ are important parameters for evaluating photosynthetic performance (Maxwell \& Johnson, 2000; Oxborough, 2004), and which decreased in gall tissues of E. uniflora. These results are similar to those found for galls induced by Bystracoccus mataybae on leaflets of Matayba guianensis (Oliveira et al., 2017), galls induced by aphids (Larson, 1998), and galls of Epiblema strenuana induced on Parthenium hysterophorus (Florentine et al., 2005).

A useful parameter for detecting biotic stress on the photosynthetic apparatus is the initial fluorescence level $\left(\mathrm{F}_{0}\right)$, which may increase when the reaction center of PSII is damaged, or if the transfer of excitation energy from the antenna complex is impaired (Bolhar-Nordenkampf et al., 1989). The high value of $\mathrm{F}_{0}$ in the galls of E. uniflora supports the idea of damage to the photosynthetic apparatus therein, probably due to oxidative stress induced by the gall-inducing insect. In addition, an important symptom of stress is a decrease in $\mathrm{R}_{\mathrm{fd}}$ (fluorescence decline ratio in steady-state), an empirical parameter used to assess plant vitality and a diagnostic parameter for plant stress (Lichtenthaler \& Miehé, 1997). The galls of E. uniflora experienced a decrease of $\mathrm{R}_{\mathrm{fd}}$ compared to non-galled leaves. Thus, $R_{\mathrm{fd}}$ can be used as an efficient parameter for measuring the biotic stress induced by gallinducing insects (Oliveira et al., 2017).

The galls of E. uniflora induced by $E$. dispar exhibited specific anatomical features, such as cell hypertrophy, hyperplasia, large intercellular spaces in the outer cell layers of the gall cortex, and nutritive tissue around the larval chamber. In this tissue, reserve compounds, especially proteins, were detected. The structural changes provoked by gall-induction deviate from the normal ontogenetical functions of the host leaves, although one of the primary functions of the leaves, photosynthesis, remains at low levels in this new organ, the gall.

\section{ACKNOWLEDGMENTS}

This work was supported by the Fundação de Amparo à Pesquisa do Estado de Minas Gerais (FAPEMIG) and Conselho Nacional de Desenvolvimento Científico e Tecnológico (CNPq). The authors thank to Ana Laura Torrano Costa and Leandro Fuzaro for all the work on the initial confections of this research. 


\section{RESUMEN}

Perfiles estructurales, histoquímicos y fotosintéticos de las agallas inducidas por Eugeniamyia dispar (Diptera: Cecidomyiidae) en las hojas de Eugenia uniflora (Myrtaceae). Los insectos que inducen las agallas manipulan los perfiles estructurales, histoquímicos y fisiológicos de los tejidos de la planta hospedera para su desarrollo. Nosotros evaluamos las agallas inducidas por Eugeniamyia dispar en las hojas de Eugenia uniflora en un intento de responder las siguientes preguntas: (i) ¿Cómo este insecto inductor de agallas cambia los perfiles estructurales e histoquímicos en el órgano de la planta hospedera? (ii) A pesar de las modificaciones estructurales, ¿pueden los tejidos de la agalla mantener la actividad fotosintética? El almidón, las proteínas, los azúcares reductores y las especies reactivas de oxígeno se detectaron principalmente en la capa de tejido nutritivo que rodea a la cavidad larval. A pesar de las modificaciones estructurales, las agallas inducidas por E. dispar en E. uniflora retienen su tejido clorofílico, aunque su cantidad y actividad fotosintética son menores que en las hojas no agalladas. Esta actividad fotosintética reducida, asociado a la presencia de grandes espacios intercelulares, pueden mejorar la difusión de gases $\mathrm{y}$, en consecuencia, evitar la hipoxia y la hipercapnia en los tejidos de las agallas.

Palabras clave: fluorescencia de la clorofila $a$; pigmentos fotosintéticos; almacenamiento de proteínas; especies reactivas de oxígeno; gradientes de tejidos.

\section{REFERENCES}

Bagatto, G., Paquette, L. C., \& Shorthouse, J. D. (1996). Influence of galls of Phanacis taraxaci on carbon partitioning within common dandelion, Taraxacum officinale. Entomologia Experimentalis et Applicata, 79, 111-117. DOI: 10.1111/j.1570-7458.1996. tb00815.x

Baker, J. R. (1958). Note on the use of bromophenol blue for the histochemical recognition of protein. The Quarterly Journal of Microscopical Science, 99, 459-460.

Bolhar-Nordenkampf, H. R., Long, S. P., Baker, N. R., Oquist, G., Schreiber, U., \& Lechner, E. G. (1989). Chlorophyll fluorescence as a probe of the photosynthetic competence of leaves in the field: a review of current instrumentation. Functional Ecology, 3, 497-514. DOI: $10.2307 / 2389624$

Bragança, G. P., Oliveira, D. C., \& Isaias, R. M. S. (2017). Compartmentalization of metabolites and enzymatic mediation in nutritive cells of Cecidomyiidae galls on Piper arboreum Aubl. (Piperaceae). Journal of Plant Studies, 6, 11-19. DOI: 10.5539/jps.v6n1p11

Bronner, R. (1992). The role of nutritive cells in the nutrition of Cynipids and Cecidomyiids. In J. D.
Shorthouse, \& O. Rohfritsch (Eds.), Biology of Insect-induced Galls (pp. 118-140). New York, United States: Oxford University Press.

Brundett, M. C., Kendrick, B., \& Peterson, C. A. (1991). Efficient lipid staining in plant material with Sudan Red 7B or fluorol yellow 088 in polyethylene glycolglycerol. Biotechnic \& Histochemistry, 66, 111-116. DOI: $10.3109 / 10520299109110562$

Carneiro, R. G. S., Castro, A. C., \& Isaias, R. M. S. (2014). Unique histochemical gradients in a photosynthesisdeficient plant gall. South African Journal of Botany, 92, 97-104. DOI: 10.1016/j.sajb.2014.02.011

Carneiro, R. G. S., \& Isaias, R. M. S. (2015). Cytological cycles and fates in Psidium myrtoides are altered towards new cell metabolism and functionalities by the galling activity of Nothotrioza myrtoidis. Protoplasma, 252, 637-646. DOI: 10.1007/ s00709-014-0709-x

Carneiro, R. G., Isaias, R., Moreira, A. S., \& Oliveira, D. C. (2017). Reacquisition of New Meristematic Sites Determines the Development of a New Organ, the Cecidomyiidae Gall on Copaifera langsdorffii Desf. (Fabaceae). Frontiers in Plant Science, 8, 1622.

Castro, A. C., Oliveira, D. C., Moreira, A. S. F. P., LemosFilho, J. P., \& Isaias, R. M. S. (2012). Source sink relationship and photosynthesis in the horn-shaped gall and its host plant Copaifera langsdorffii Desf. (Fabaceae). African Journal of Botany, 83, 121-126. DOI: $10.1016 /$ j.sajb.2012.08.007

Del Río, L. A., \& Puppo, A. (2009). Reactive oxygen species in plant signaling. Heidelberg, Germany: Springer-Verlag.

Demmig-Adams, B., \& Adams, W. W. (1996). The role of xanthophyll cycle carotenoids in the protection of photosynthesis. Trends in Plant Science, 1, 21-26. DOI: 10.1016/S1360-1385(96)80019-7

Fernandes, G. W., Coelho, M. S., \& Lüttge, U. (2010). Photosynthetic efficiency of Clusia arrudae leaf tissue with and without Cecidomyiidae galls. Brazilian Journal of Biology, 70, 723-728. DOI: 10.1590/ S1519-69842010000400004

Fernandes, G. W., \& Santos, J. C. (2014). Neotropical insect galls. Dordrecht, Holland: Springer.

Ferreira, B. G., \& Isaias, R. M. S. (2013). Developmental stem anatomy and tissue redifferentiation induced by a galling Lepidoptera on Marcetia taxifolia (Melastomataceae). Botany, 91, 752-760. DOI: 10.1139/ cjb-2013-0125

Ferreira, B. G., Teixeira, C. T., \& Isaias, R. M. S. (2014). Efficiency of the polyethylene-glycol (PEG) embedding medium for plant histochemistry. The Journal of Histochemistry and Cytochemistry, 62, 577-583. DOI: 10.1369/0022155414538265 
Ferreira, B. G., \& Isaias, R. M. S. (2014). Floral-like destiny induced by a galling Cecidomyiidae on the axillary buds of Marcetia taxifolia (Melastomataceae). Flora, 209, 391-400. DOI: 10.1016/j. flora.2014.06.004

Ferreira, B. G., Álvarez, R., Avritzer, S. C., \& Isaias, R. M. S. (2017). Revisiting the histological patterns of storage tissues: beyond the limits of gall-inducing taxa. Botany, 95, 173-184. DOI: 10.1139/cjb-2016-0189

Florentine, S. K., Raman, A., \& Dhileepan, K. (2005). Effects of gall induction by Epiblema strenuana on gas exchange, nutrients, and energetics in Parthenium hysterophorus. BioControl, 50, 787-801. DOI: $10.1007 / \mathrm{s} 10526-004-5525-3$

Formiga, A. T., Gonçalves, S. J. M. R., Soares, G. L. G., \& Isaias, R. M. S. (2009). Relações entre o teor de fenóis totais e o ciclo das galhas de Cecidomyiidae em Aspidosperma spruceanum Müell. Arg. (Apocynaceae). Acta Botanica Brasilica, 23, 93-99. DOI: 10.1590/S0102-33062009000100012

Formiga, A. T., Soares, G. L. G., \& Isaias, R. M. S. (2011). Responses of the host plant tissues to gall induction in Aspidosperma spruceanum Müell. Arg. (Apocynaceae). American Journal of Plant Sciences, 2, 823834. DOI: $10.4236 /$ ajps.2011.26097

Gagné, J. R. (1994). The gall midges of the Neotropical region. Ithaca, United States: Cornell University Press.

Genty, B., Briantais, J. M., \& Baker, N. R. (1989). The relationship between the quantum yield of photosynthetic electron transport and quenching of chlorophyll fluorescence. Biochimica et Biophysica Acta, 990, 87-92. DOI: $10.1016 / \mathrm{S} 0304-4165(89) 80016-9$

Haiden, S. A., Hoffmann, J. H., \& Cramer, M. D. (2012). Benefits of photosynthesis for insects in galls. Oecologia, 170, 987-997. DOI: 10.1007/s00442-012-2365-1

Heldt, W., \& Piechulla, B. (2010). Plant biochemistry. London, England: Academic Press.

Isaias, R. M. S., Oliveira, D. C., \& Carneiro, R. G. S. (2011). Role of Euphalerus ostreoides (Hemiptera: Psylloidea) in manipulating leaflet ontogenesis of Lonchocarpus muehlbergianus (Fabaceae). Botany, 89, 581-592. DOI: 10.1139/b11-048

Isaias, R. M. S., Carneiro, R. G. S., Oliveira, D. C., \& Santos, J. C. (2013). Illustrated and annotated checklist of Brazilian gall morphotypes. Neotropical Entomology, 42,230-239. DOI: 10.1007/s13744-013-0115-7

Isaias, R. M. S., Oliveira, D. C., Carneiro, R. G. S., \& Kraus, J. E. (2014). Developmental anatomy of galls in the neotropics: arthropods stimuli versus host plant constraints. In G. W. Fernandes, \& J. C. Santos (Eds.), Neotropical insect galls (pp. 15-34). Brazil: Springer.
Isaias, R. M. S., Oliveira, D. C., Moreira, A. S. F. P., Soares, G. L. G., \& Carneiro, R. G. S. (2015). The imbalance of redox homeostasis in arthropod-induced plant galls: mechanisms of stress generation and dissipation. Biochimica et Biophysica Acta, 1850, 15091517. DOI: $10.1016 /$ j.bbagen.2015.03.007

Johansen, D. A. (1940). Plant microtechnique. New York, United States: McGraw-Hill.

Larson, K. C. (1998). The impact of two gall-forming arthropods on the photosynthetic rates of their hosts. Oecologia, 115, 161-166. DOI: 10.1007/ s004420050503

Lev-Yadun, S. (2003). Stem cell in plants are differentiated too. Current Topics in Plant Biology, 4, 93-100. DOI: 10.1016/j.cell.2005.08.006

Lichtenthaler, H. K. \& Wellburn, A. R. (1983). Determinations of total carotenoids and chlorophylls $a$ and $b$ of leaf extracts in different solvents. Biochemical Society Transactions, 11, 591-592. DOI: 10.1042/bst0110591

Lichtenthaler, H. K., \& Miehé, J. A. (1997). Fluorescence imaging as a diagnostic tool for plant stress. Trends in Plant Science, 2, 316-319. DOI: 10.1016/ S1360-1385(97)89954-2

Magalhães, T. A., Oliveira, D. C., Suzuki, A. Y. M., \& Isaias, R. M. S. (2014). Patterns of cell elongation in the determination of the final shape in galls of $\mathrm{Bac}$ charopelma dracunculifoliae (Psyllidae) on Baccharis dracunculifolia DC (Asteraceae). Protoplasma, 251, 747-753. DOI: 10.1007/s00709-013-0574-z

Maia, V. C., Mendonça, M. S., \& Romanowski, H. P. (1996). Eugeniamyia díspar gen.n. and sp.n. (Diptera, Cecidomyiidade, Lasiopteridi) associated with Eugenia uniflora L. (Myrtaceae) in Brazil. Revista Brasileira de Zoologia, 13, 1087-1090. DOI: 10.1590/S0101-81751996000400026

Mani, M. S. (1964). Ecology of Plant Galls. Netherlands: Dr. W. Junk Publishers, The Hague.

Maxwell, K., \& Johnson, G. N. (2000). Chlorophyll fluorescence-a practical guide. Journal of Experimental Botany, 51, 659-668.

Mendonça, M. S., \& Romanowski, H. P. (2002). Natural enemies of the gall-maker Eugenia dispar (Diptera, Cecidomyiidae): predatory ants and parasitoids. Brazilian Journal of Biology, 62, 269-275. DOI: 10.1590/S1519-69842002000200011

Moura, M. Z. D., Soares, G. L. G., \& Isaias, R. M. S. (2008). Species-specific changes in tissue morphogenesis induced by two arthropod leaf gallers in Lantana camara L. (Verbenaceae). Australian Journal of Botany, 53, 153-160. DOI: 10.1071/BT07131

O’Brien, T. P., Feder, N., \& Mccully, M. E. (1964). Polychromatic staining of plant cell walls by toluidine 
blue O. Protoplasma, 59, 368-373. DOI: 10.1007/ BF01248568

Oliveira, D. C., \& Isaias, R. M. S. (2010a). Redifferentiation of leaflet tissues during midrib gall development in Copaifera langsdorffii (Fabaceae). South African Journal of Botany, 76, 239-248. DOI: 10.1016/j. sajb.2009.10.011

Oliveira, D. C. \& Isaias, R. M. S. (2010b). Cytological and histochemical gradients induced by a sucking insect in galls of Aspidosperma australe Arg. Muell (Apocynaceae). Plant Science (Limerick), 178, 350-358.

Oliveira, D. C., Magalhães, T. A.; Carneiro, R. G. S., Alvim, M. N., \& Isaias, R. M. S. (2010). Do Cecidomyiidae galls of Aspidosperma spruceanum (Apocynaceae) fit the pre-established cytological and histochemical patterns? Protoplasma, 242, 81-93.

Oliveira, D. C., Carneiro, R. G. S., Magalhaes, T. A., \& Isaias, R. M. S. (2011a). Cytological and histochemical gradients on two Copaifera langsdorffii Desf. (Fabaceae) - Cecidomyiidae gall systems. Protoplasma, 248, 829-837. DOI: $10.1105 /$ tpc. 010454

Oliveira, D. C., Isaias, R. M. S., Moreira, A. S. F. P., Magalhães, T. A., \& Lemos-Filho, J. P. (2011b). Is the oxidative stress caused by Aspidosperma spp. galls capable of altering leaf photosynthesis? Plant Sciences, 180, 489-495. DOI: 10.1016/j. plantsci.2010.11.005

Oliveira, D. C., Isaias, R. M. S., Fernandes, G. W., Ferreira, B. G., Carneiro, R. G. S., \& Fuzaro, L. (2016). Manipulation of host plant cells and tissues by gall-inducing insects and adaptive strategies used by different feeding guilds. Journal of Insect Physiology, 84, 103-113. DOI: 10.1016/j.jinsphys.2015.11.012

Oliveira, D. C., Moreira, A. S. F. P., Isaias, R. M. S., Martini, V., \& Rezende, U. (2017). Sink status and photosynthetic rate of the leaflet galls induced by Bystracoccus mataybae (Eriococcidae) on Matayba guianensis (Sapindaceae). Frontiers in Plant Science, 8, 1-12. DOI: 10.3389/fpls.2017.01249

Oxborough, K. (2004). Imaging of chlorophyll a: theoretical and practical aspects of an emerging technique for the monitoring of photosynthetic performance. Journal of Experimental Botany, 55, 1195-1205. DOI: $10.1093 / \mathrm{jxb} / \mathrm{erh} 145$

Petrov, V. D., \& Van Breusegem, F. (2012). Hydrogen peroxide-a central hub for information flow in plant cells. AoB Plants, 2012, pls014. DOI: 10.1093/ aobpla/pls014

Pincebourde, S., \& Casas, J. (2016). Hypoxia and hypercarbia in endophagous insects: Larval position in the plant gas exchange network is key. Journal of Insect Physiology, 84, 137-153. DOI: 10.1016/j. jinsphys.2015.07.006
Price, P. W., Fernandes, G. W., \& Warring, G. L. (1987). Adaptive nature of insect galls. In V. Labeyre, G. Fabres, \& D. Lachaise (Eds.), Insects-plants (pp. 15-24). Dordrecht, Netherlands: Dr. W. Junk Publish.

Raman, A., Schaefer, C. W., \& Withers, T. M. (2005). Biology, ecology, and evolution of gall-inducing arthropods. New Hampshire, United States: Science Publishers, Inc.

Raman, A., Cruz, Z. T., Muniappan, R., \& Reddy, G. V. P. (2007). Biology and host specificity of gall-inducing Acythopeus (Coleoptera: Curculionidae: Baridinae), a biological control agent for the invasive weed $\mathrm{Coc}$ cinia grandis (Cucurbitaceae) in Guam and Saipan. Tijdschrift voor Entomologie, 150, 181-191. DOI: $10.1163 / 22119434-900000217$

Roskam, J. C. (1992). Evaluation of the gall-inducing guild. In J. D. Shorthouse \& O. Rohfritsch (Eds.), Biology of insect-induced galls (pp. 34-39). New York, United States: Oxford.

Rossetti, S., \& Bonnatti, P. M. (2001). In situ histochemical monitoring of ozone- and TMV induced reactive oxygen species in tobacco leaves. Plant Physiology and Biochemistry, 39, 433-442. DOI: 10.1016/S0981-9428(01)01250-5

Sass, J. E. (1951). Botanical microtechnique. Ames, United States: Iowa State College Press.

Schönrogge, K., Harper, L. J., \& Lichtenstein, C. P. (2000). The protein contente of tissue in cynipid galls (Hymenoptera: Cynipidae): similarities between cynipid galls and seeds. Plant, Cell \& Environment, 23, 215222. DOI: $10.1046 /$ j.1365-3040.2000.00543.x

Shorthouse, J. D. \& Rohfritsch, O. (1992). Biology of insect-induced galls. New York, United States: Oxford University Press.

Shorthouse, J. D., Wool, D., \& Raman, A. (2005). Gallinducing insects - Nature's most sophisticated herbivores. Basic and Applied Ecology, 6, 407-411. DOI: 10.1016/j.baae.2005.07.001

Stone, G. N., \& Schönrogge, K. (2003). The adaptive significance of insect gall morphology. Trends in Ecology \& Evolution, 18, 512-522. DOI: 10.1016/ S0169-5347(03)00247-7

Vecchi, C., Menezes, N. L., Oliveira, D. C., Ferreira, B. G., \& Isaias, R. M. S. (2013). The redifferentiation of nutritive cells in galls induced by Lepidoptera on Tibouchina pulchra (Cham.) Cogn. reveals predefined patterns of plant development. Protoplasma, 250, 1363-1368. DOI: 10.1007/s00709-013-0519-6

Victoria, F. N., Lenardão, E. J., Savegnago, L., Perin, G., Jacob, R. G., Alves, D., \& Nascente, P. S. (2012). Essential oil of the leaves of Eugenia uniflora L.: antioxidant and antimicrobial properties. Food and chemical toxicology, 50, 2668-2674. DOI: 10.1016/j. fct.2012.05.002 